\title{
Pelatihan Manajemen Pakan untuk Meningkatkan Efisiensi Produksi Peternakan Sapi Potong Rakyat
}

\author{
Adi Ratriyanto*, Rendi Fathoni Hadi, Susi Dwi Widyawati \\ Program Studi Peternakan, Fakultas Pertanian, Universitas Sebelas Maret, Surakarta \\ *ratriyanto@staff.uns.ac.id
}

\begin{abstract}
Abstrak
Pakan merupakan salah satu faktor penentu keberhasilan dalam usaha ternak sapi potong. Pakan yang diberikan harus memenuhi kuantitas dan kualitas sesuai dengan kebutuhan ternak. Oleh karena itu diperlukan manajemen pakan yang baik, meliputi aspek pemilihan, penyimpanan, pengolahan dan pengawetan, serta metode pemberian pakan kepada ternak. Kegiatan pengabdian ini bertujuan untuk memberikan pelatihan manajemen pakan bagi peternak sapi potong di Desa Pelemrejo, Kecamatan Andong, Kabupaten Boyolali. Seperti halnya wilayah lain di Boyolali, sapi potong dipelihara sebagai salah satu bagian dari sistem pertanian yang berfungsi sebagai tabungan, penghasil kotoran maupun untuk tenaga kerja. Beberapa permasalahan dalam manajemen pakan yang teridentifkasi adalah peternak tidak mengetahui kualitas masing-masing bahan pakan dan pemberian pakan tidak terukur sehingga terjadi pemborosan bahan pakan. Kegiatan ini dilakukan dengan memberikan penyuluhan dan pelatihan manajemen pakan bagi peternak sapi potong, seperti pengenalan kualitas pakan, pengolahan dan penyimpanan pakan, serat metode pemberian pakan. Diakhir program pengabdian, peternak mampu melakukan manajemen pakan ternak sapi secara baik untuk menghasilkan pertumbuhan ternak dan keuntungan yang optimal.
\end{abstract}

Kata kunci-Peternak, sapi potong, manajemen pakan, produktivitas

\section{Pendahuluan}

Kebutuhan daging di Indonesia yang terus meningkat dan cita-cita untuk swasembada pangan menuntut peningkatan produksi daging dalam negeri. Tuntutan ini terbawa hingga produksi di peternakan tradisional yang tersebar luas di Indonesia. Akan tetapi, dalam upaya peningkatan produktivitas ternak sapi, masih banyak kendala yang dihadapi sehingga produksi daging belum maksimal yang telihat pada realisasi program swasembada sapi potong yang dinilai masih belum memenuhi kebutuhan dalam negri (Winarso, 2017). Hal ini terlihat pada tahun 2018 dimana kebutuhan daging sebanyak 663.290 ton belum terpenuhi dengan produksi daging yang hanya sebesar 403.668 ton (Jannan dan Supriyono, 2018).

Salah satu penyebab produktivitas yang kurang optimal adalah tidak terpenuhinya kebutuhan nutrien dari pakan. Pakan merupakan salah satu faktor penentu keberhasilan dalam usaha ternak sapi potong. Pakan yang diberikan harus memenuhi kuantitas dan kualitas sesuai dengan kebutuhan ternak (Yulianto, dan Saparinto, 2014). Manajemen pakan sapi potong mencakup pemilihan, pengolahan, pengawetan dan pemberian bahan pakan kepada ternak sesuai dengan kebutuhan untuk pertumbuhan. Tidak terpenuhinya kebutuhan nutrien berdampak langsung terhadap penurunan pembentukan daging dan produktivitas sapi (Abidin, 2008). Oleh karena itu, dibutuhkan tindakan khusus untuk mengendalikan kejadian penyakit pada ternak yang secara umum terbagi menjadi tindakan pencegahan (preventive), tindakan pengobatan (curative), dan rehabilitasi (rehabilitation).

Desa Pelemrejo, Kecamatan Andong, Kabupaten Boyolali, merupakan daerah pertanian dengan salah satu bentuk usahanya adalah beternak sapi potong. Sapi potong di desa ini dimanfaatkan dalam bentuk daging maupun kotoran untuk pupuk sehingga memberikan penghasilan tambahan bagi masyarakatnya. Tata laksana manajemen pakan sapi potong di tingkat peternak dapat dilakukan terutama pemberian pakan yang mencukupi kandungan nutrien dengan 
jumlah cukup. Jumlah pakan yang diberikan harus cukup, dalam arti tidak kekurangan dan tidak berlebihan. Penerapan manajemen pakan di lapangan pada tingkat peternak rakyat belum maksimal disebabkan oleh kurangnya pengetahuan tentang bahan pakan dan kebutuhan nutrien ternak sapi potong. Hal ini juga dikarenakan banyak peternak tradisional yang melaksanakan budidaya ternak sebagai kegiatan sambilan disamping aktivitas utamanya sebagai petani. Untuk itu, diperlukan diseminasi pengetahuan mengenai manajemen pakan sapi kepada peternak.

Berdasarkan survey yang sudah dilakukan, manajemen pakan di daerah ini masih belum dilaksanakan dengan baik, sehingga pertumbuhan ternak tidak optimal dan banyak penyakit pada sapi yang ditemukan. Selain itu, kondisi badan sapi menunjukkan body conditioning score (BCS) yang kurang baik untuk sapi potong yang merupakan salah satu indikasi adanya gangguan pertumbuhan atau gangguan kesehatan. Selain itu kebersihan dan kesehatan kandang di peternakan yang ada di Desa Pelemrejo terlihat belum sesuai standar seperti adanya pakan yang tercecer, menunjukkan manajemen pakan yang tidak baik. Oleh karena itu, daerah ini dirasa cocok sebagai lokasi pengabdian untuk peningkatan tata laksana manajemen pakan sapi potong.

Masalah utama peternak sapi potong di Desa Pelemrejo, Kecamatan Andong, Kabupaten Boyolali adalah keterbatasan pengetahuan peternak mengenai manajemen pakan ternak sapi, antara lain ditunjukkan dari:

- Pemberian pakan tidak dilakukan dengan tepat, baik dari aspek ketercukupan kebutuhan nutrien, metode pemberian maupun jumlah pakan yang diberikan.

- Keterbatasan kemampuan pengetahuan dan ketrampilan dalam pembuatan pakan.

Hal tersebut menyebabkan rendahnya produktivitas sehingga pendapatan peternak di desa ini tidak maksimal, misalnya kondisi badan sapi menunjukkan BCS yang kurang baik untuk sapi potong. Oleh karena itu, peternak perlu untuk dibekali mengenai manajemen pakan yang baik dan benar. Kegiatan pengabdian ini bertujuan untuk memberikan penyuluhan dan pelatihan manajemen pakan sapi potong di Desa Pelemrejo, Kecamatan Andong, Kabupaten Boyolali.

\section{Metode Pelaksanaan}

Program pengabdian ini dibagi menjadi 3 tahap utama. Tahap 1 adalah tahap survey dan sosialisasi, tahap 2 adalah pelaksanaan kegiatan dan tahap 3 adalah evaluasi dan diseminasi hasil.

\section{Survey dan Sosialisasi}

Langkah pertama yang dilaksanakan dalam program ini adalah survey untuk mengetahui manajemen pakan sapi potong yang dilaksanakan oleh peternak di Desa Pelemrejo, Kecamatan Andong, Kabupaten Boyolali. Hasil temuan di lapangan ini digunakan sebagai materi penyuluhan dan pelatihan. Kegiatan ini diawali dengan sosialisasi program dengan Kepala Desa, perangkat desa dan tokoh masyarakat. Rencana pengabdian dipaparkan untuk memberikan gambaran secara menyeluruh tentang program oleh tim pengabdi. Kegiatan dilanjutkan dengan survey kondisi peternakan sapi di lingkungan setempat.

\section{Penyuluhan}

Upaya peningkatan kualitas peternak dalam menjalankan tata laksana manajemen pakan sapi potong di Desa Pelemrejo, Kecamatan Andong, Kabupaten Boyolali dilakukan dengan cara penyuluhan dan pelatihan. Penyuluhan dilaksanakan dengan mengundang peserta seluruh peternak sapi potong di Desa Pelemrejo. Materi yang disampaikan berupa manajemen pakan yang dapat dilakukan oleh peternak dan disampaikan oleh tim pengabdi.

\section{Pelatihan}

Pelatihan manajemen pakan diberikan dengan materi antara lain pelatihan pengolahan dan pengawetan pakan, dan pelatihan pemberian pakan dengan jumlah dan metode yang benar.

\section{Hasil Dan Pembahasan}

\section{Survey dan Sosialisasi}

Berdasarkan survey yang sudah dilakukan, manajemen pakan di daerah ini masih belum dilaksanakan dengan baik, sehingga pertumbuhan ternak tidak optimal dan banyak penyakit pada sapi yang ditemukan. Selain itu, kondisi badan sapi menunjukkan BCS yang kurang baik untuk sapi potong yang merupakan salah satu indikasi adanya 
gangguan pertumbuhan atau gangguan kesehatan. Selain itu higiene kandang di peternakan yang ada di Desa Pelemrejo terlihat belum sesuai standar seperti adanya pakan yang tercecer, menunjukkan manajemen pakan yang tidak baik.

\section{Penyuluhan}

Kegiatan tahap pelaksanaan (Gambar 1 dan Gambar 2), telah dilaksanakan dengan mitra peternak sapi warga Desa Pelemrejo, Kecamatan Andong, Kabupaten Boyolali. Pada tanggal yang telah ditetapkan dilaksanakan kegiatan penyuluhan dan pelatihan. Kegiatan dilakukan di Pendopo Balai Desa Pelemrejo, Kecamatan Andong, Kabupaten Boyolali yang memiliki tempat luas dan terbuka dengan sirkulasi udara yang sangat baik. Warga sangat antusias sekali dengan penyuluhan. Mereka berharap dengan kegiatan semacam ini bisa menambah ilmu dan dapat mereka aplikasikan dalam pemberian pakan ternak sapi untuk mendukung usaha peternakan mereka.
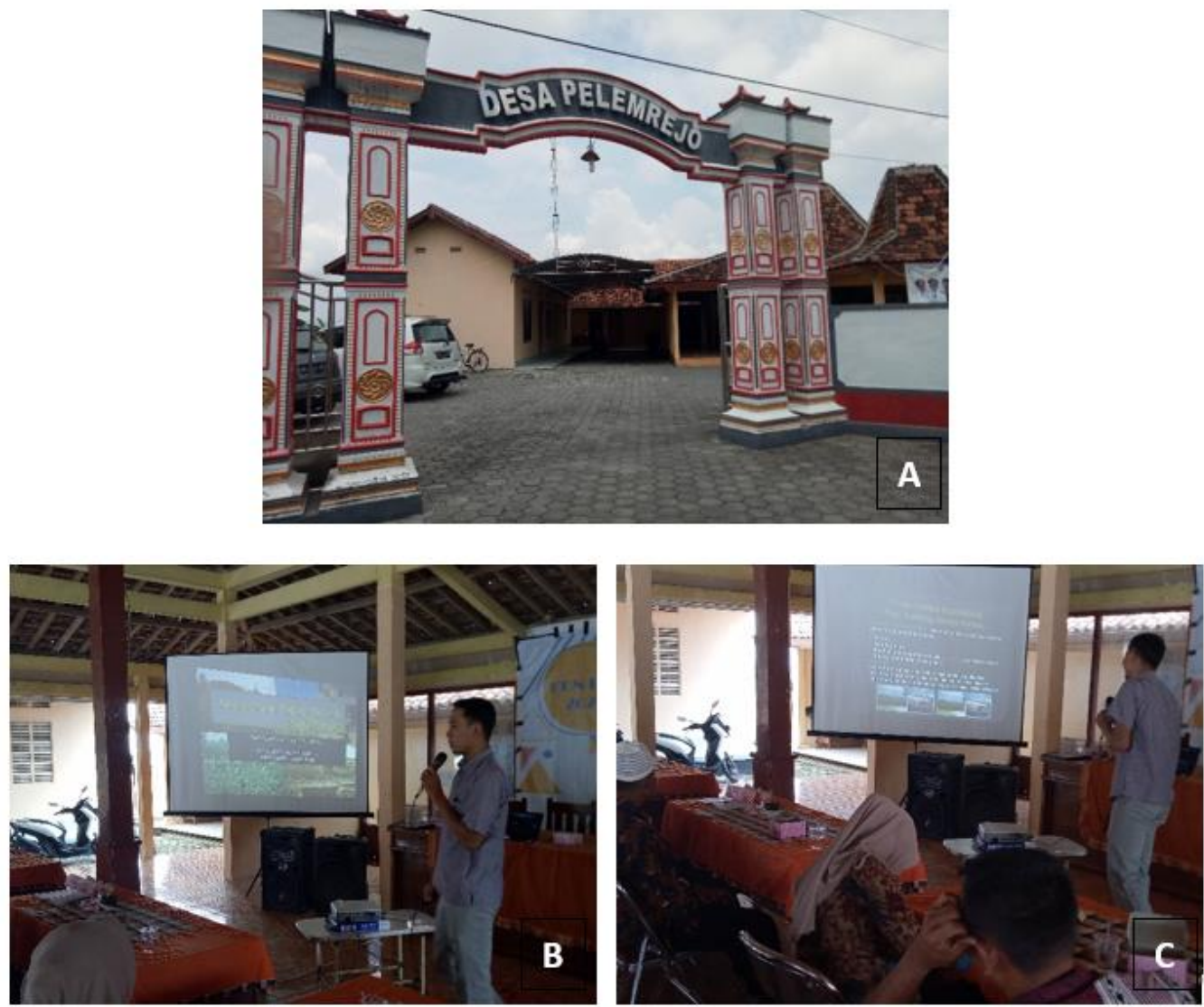

Gambar 1. Gapura Balai Desa Pelemrejo (A), Kegiatan penyuluhan dan pelatihan (B dan C)

Kegiatan penyuluhan diawali dengan sambutan oleh tim pengabdi dan Kepala Desa/Sekretaris Desa. Tim pengabdi memaparkan hendaknya kegiatan semacam ini dapat dirasakan manfaatnya oleh para peternak sapi potong. Selain itu diusahakan tidak hanya berhenti pada satu kegiatan saja tapi dapat berkelanjutan. Setelah sambutan acara dilanjutkan dengan materi disampaikan oleh narasumber. Materi penyuluhan manajemen pakan sapi potong disampaikan oleh Rendi Fathoni Hadi, S.Pt., M.P. Materi yang diberikan antara lain:

1. Memberikan pengetahuan yang lebih luas tentang manajemen pakan yang terprogram, kegiatan ini dilakukan dengan penyuluhan dan pendampingan.

2. Memberikan pengetahuan mengenai pentingnya pakan konsentrat dan suplemen. Kegiatan ini dilakukan dengan penyuluhan, pelatihan dan pendampingan.

3. Aplikasi manajemen pakan dengan pemilihan bahan baku pakan yang ada di sekitar lokasi. 

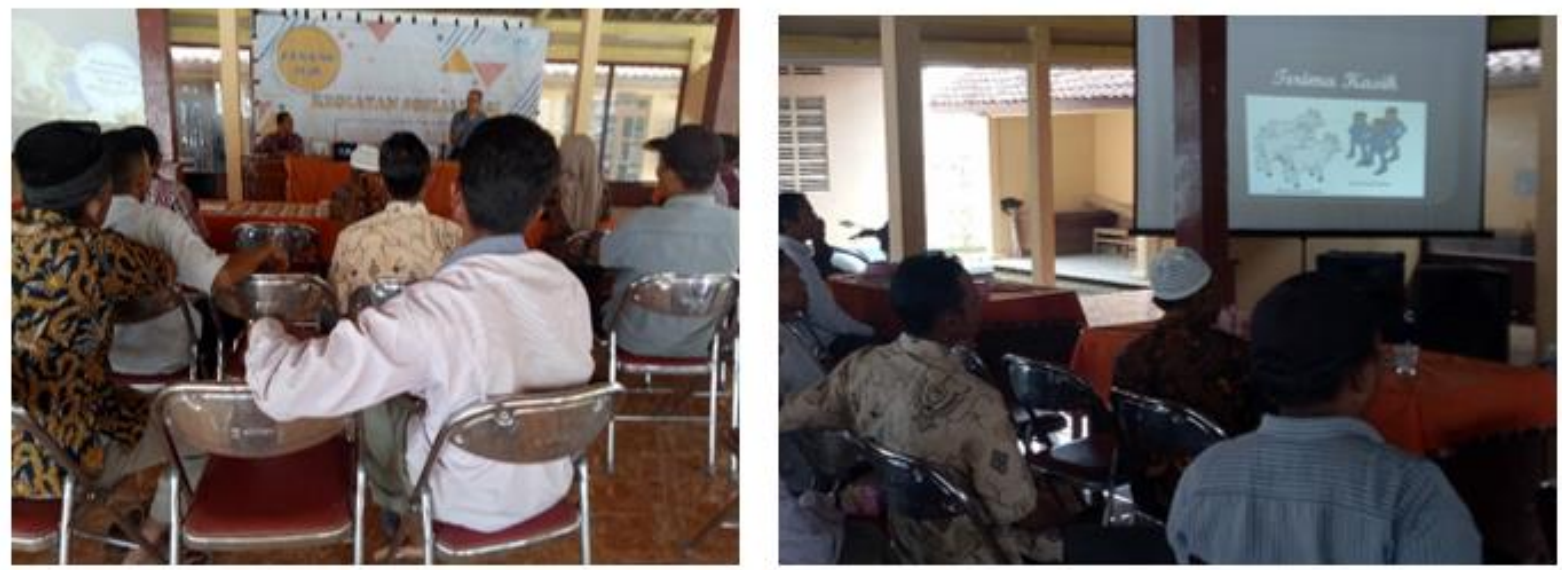

Gambar 2. Peserta mengikuti kegiatan dengan seksama

Setelah sesi penyampaian materi oleh narasumber dilakukan tanya jawab. Peserta sangat aktif berdiskusi dan bertanya dengan narasumber (Gambar 3). Pada sesi ini dapat dilihat bahwa sebenarnya peternak sudah mengetahui tentang penilaian kualitas pakan, tetapi belum dilakukan program pengolahan pakan. Sumber pakan di Desa Pelemrejo juga cukup baik dilihat dari jumlah dan kualitas. Mayoritas masyarakat berprofesi sebagai petani, seperti padi dan jagung, sehingga jerami padi dan jerami jagung dapat digunakan sebagai sumber pakan ternak. Pemberian pakan konsentrat belum dilakukan secara rutin. Selan itu, pemberian pakan tidak diukur dengan tepat sehingga menyebabkan banyak pakan yang terbuang dan tidak dikonsumsi oleh ternak sapi.

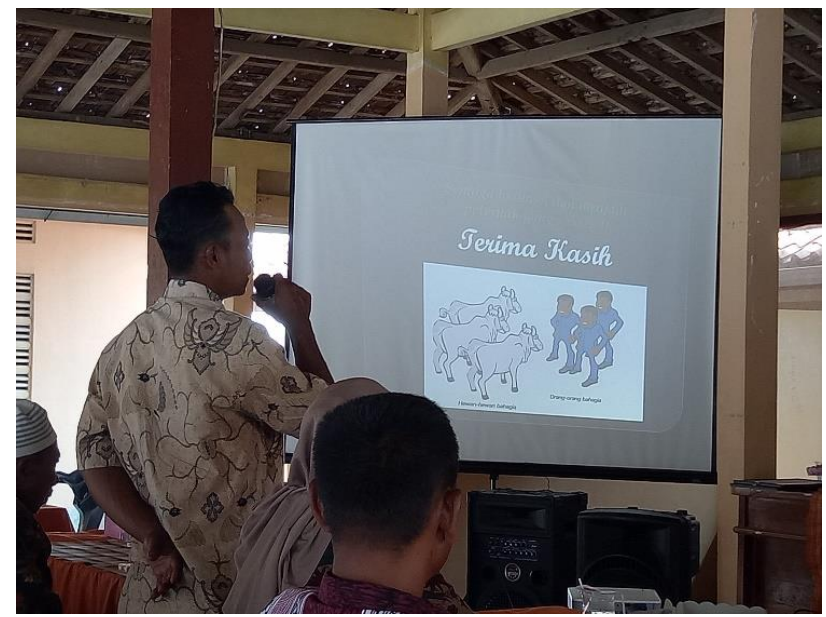

Gambar 3. Peserta mengikuti kegiatan dengan seksama dengan penerapan social distancing

\section{Pelatihan}

Tim pengabdi memberikan penjelasan dan informasi secara singkat tentang manajemen pakan yang mencakup pengolahan dan pengawetan pakan, pelatihan pemberian pakan dengan jumlah dan metode yang benar, dan pembuatan pakan suplemen.

Hasil kegiatan berupa penyuluhan manajemen pakan dan pelatihan pengolahan dan pengawetan pakan, serta pelatihan pemberian pakan dengan jumlah dan metode yang benar akan diterapkan dalam pemeliharaan sapi potong oleh peternak (Gambar 4). Dengan penerapan manajemen pakan yang baik, diharapkan dapat terjadi efisiensi penggunaan bahan pakan, dan tetap diperoleh pertumbuhan ternak yang baik, sehingga hal ini akan lebih menguntungkan peternak sapi potong. 

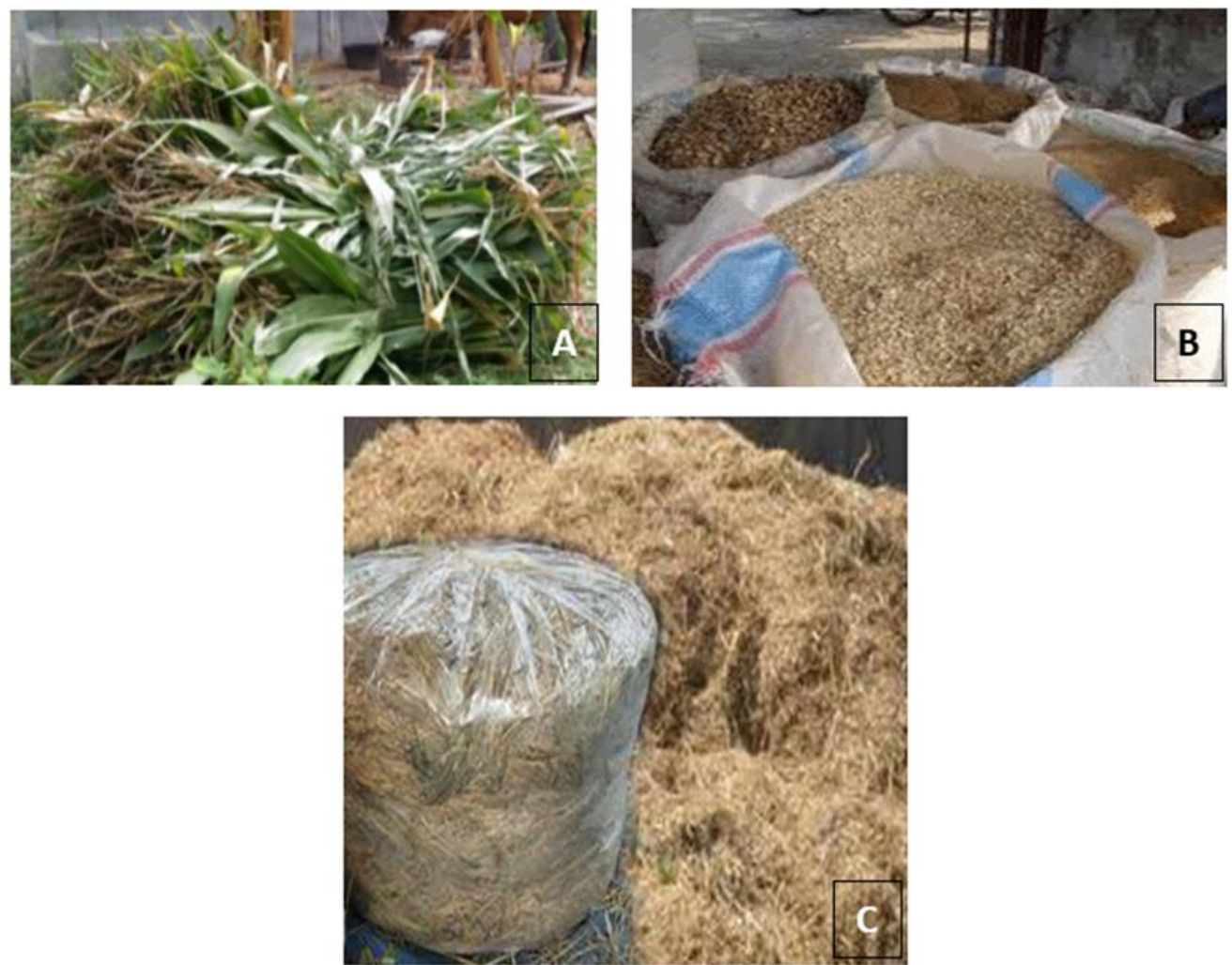

Gambar 4. Bahan pakan hijauan (A), bahan pakan konsentrat (B), pengolahan pakan (C).

\section{Kesimpulan}

Kegiatan penyuluhan dan pelatihan manajemen pakan dapat meningkatkan pemahaman peternak sapi potong mengenai pengolahan dan pengawetan pakan, serta pelatihan pemberian pakan dengan jumlah dan metode yang benar. Penerapan manajemen pakan yang baik dalam pemeliharaan sapi potong diharapkan dapat meningkatkan efisiensi penggunaan bahan pakan, dan tetap diperoleh pertumbuhan ternak yang baik, sehingga akan lebih menguntungkan peternak sapi potong.

\section{Daftar Pustaka}

Abidin, I. Z, 2008, Penggemukan Sapi Potong, AgroMedia, Jakarta.

Jannan, M. M., \& Supriyono, H. 2018. Sistem Pendukung Keputusan untuk Penyakit Sapi Berbasis Android, Emitor: Jurnal Teknik Elektro, 18(2), hal 8-13.

Winarso, B., 2017, Realisasi kegiatan program daerah dalam pengembangan pembibitan sapi potong guna mendukung swasembada daging nasional, Jurnal Penelitian Pertanian Terapan, 14(2), hal 111-123.

Yulianto, P. dan Saparinto, C., 2014, Beternak Sapi Limousin, Penebar Swadaya Grup, Jakarta. 